\title{
A FENNTARTHATÓSÁGRA NEVELÉS HELYZETKÉPE A TERMÉSZETTUDOMÁNYOS NEVELÉSBEN
}

\section{Majer Anna}

Oktatáskutató és Fejlesztő Intézet, Budapest, Magyarország

Kutatásunk a TÁMOP 3.1.1 XXI. századi közoktatás (fejlesztés, koordináció) II. szakaszprojekt „Nevelés-oktatás fejlesztése, komplex pilot programok” alprojektjének keretein belül - 2013 tavaszán a magyarországi általános iskolák igazgatóinak kiküldött kérdöívből visszaérkezett 641 teljesen kitöltött kérdőív adatain alapul. A településlista diverz, sok településről érkezett kitöltött kérdőív. Az iskolák jellege is széles skálán mozog, a kistelepülési iskoláktól egészen az egyetemi gyakorlóiskolákig. A 83 pontból álló kérdőív az alprojekt összes témacsoportjának munkáját segítette, de jelen elemzésünkben csak a természettudományi témacsoport számára releváns eredményeket ismertetjük, elsősorban a fenntartható fejlődés pedagógiai módszereinek (Havas, 2009) megjelenésére, a természettudományok tanításával kapcsolatos módszertani jellemzőkre, a tanórákon alkalmazott eszközökre, a rendelkezésre álló infrastruktúrára, és a jellemző tanórán kívüli tevékenységekre koncentráltunk.

Kutatás-fejlesztés-innovációs projektünk keretében hét elemü nevelésioktatási programot szeretnénk kidolgozni, együttmüködő iskolákat bevonva, mely támogatja a fenntarthatóság pedagógiáját, és a felfedeztető tanulást a természettudományos nevelésben. Szándékunk szerint a program moduljai mind a szakköri foglalkozásokon, mind a tanítási órákon jól alkalmazhatóak lesznek. A program sikeressége érdekében mértük fel az általános iskolák jelenlegi helyzetét a fent említett szempontok figyelembevételével, hogy a valós napi gyakorlatból indulhasson ki fejlesztési tervünk.

Elemzésünk során kiemelt szerepet kapott a fenntarthatóság pedagógiájának alkalmazása, az aktív tanulási-tanítási módszerek bevezetésének lehetőségei, az iskolák környezeti neveléssel kapcsolatos attitüdjei. A kitöltők között összesen 145 ökoiskola szerepel, bizonyos jellemzőket - melyek megjelenésére egy ökoiskolai címmel rendelkező intézmény esetében nagyobb valószínűséggel számítottunk - ebben a körben vizsgáltunk.

Fenntarthatóság alatt az UNESCO (1992.) által is elfogadott fogalmat értjük, mely a gazdaság, a környezet és a társadalom szempontjait egyaránt figyelembe veszi. „A fenntartható fejlődés a tágan értelmezett életminőség javulását szolgálja, ezért a szociális jólét elérését, megtartását elősegítő gazdasági fejlődéssel együtt kell érvényesülnie a szociális igazságosságnak és az esélyegyenlőségnek, valamint a természeti erőforrásokkal való fenntartható gazdálkodásnak." Ebből következik, hogy ennek a három területnek a fenntarthatóság pedagógiájában is érvényesülnie kell. Ennek célja, hogy olyan felelősen gondolkodó embereket neveljen, akik képesek az önálló gondolkodásra, 
döntéshozásra, az új ismeretek befogadására, összefüggések felismerésére. Mindezt olyan szellemben, hogy szem előtt tartsák a környezetvédelem, a társadalmi igazságosság és a gazdaság érdekeit, törékeny egyensúlyát is. Ezek a célok újszerü pedagógiai megközelítést igényelnek, melynek része a szituált tanulás, a helyi tudás beépítése, a problémamegoldás, vita, kommunikáció, kreativitás. El kell érni, hogy a tanulóknak igényük legyen a tények feltárására, képesek legyenek az önálló vizsgálódásra, kísérletezésre, eredményeik értelmezésére, kontextusba helyezésére. A fenntarthatóság pedagógiája rendkívül komplex szemléletet követel, melynek - mint az 1. ábrán is látszik - a környezeti nevelés csupán egyik aspektusa.

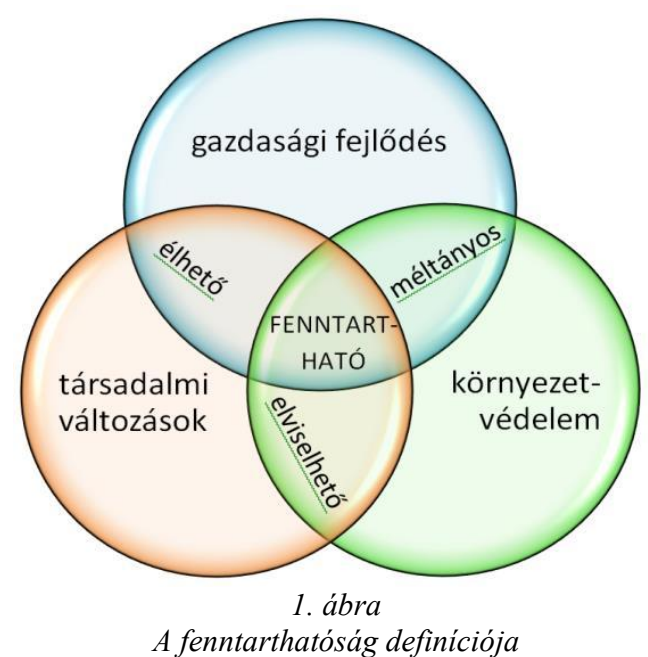

A sokrétű célrendszer gazdag módszertani eszköztárat követel, emellett a valós élet problémáinak beemelését a tanterembe. A válaszadó iskolákban a következő módszertani eszközöket alkalmazzák a pedagógusok: a differenciálás és a csoportmunka az iskolák nagy többségében megjelenik, kooperatív technikákat kétharmaduk használ. Ez jó kiindulási alap lehet a kidolgozandó nevelési oktatási programunk számára. A fenntarthatóság pedagógiájának szempontjait figyelembe véve pozitív változás lehetne a tematikus feldolgozás és a projektmódszer használati gyakoriságának növelése, ezekkel a módszerekkel könnyebben dolgozhatók fel például legitim kérdések (Lave, 2009, idézi Réti, 2013) a tanítási órán. Az itt felsoroltakon kívül más módszerek is eredményesek lennének a fenntarthatóság pedagógiája és a felfedeztető tanulás szempontjából, de azok nem jelentek meg a felmérés során. 


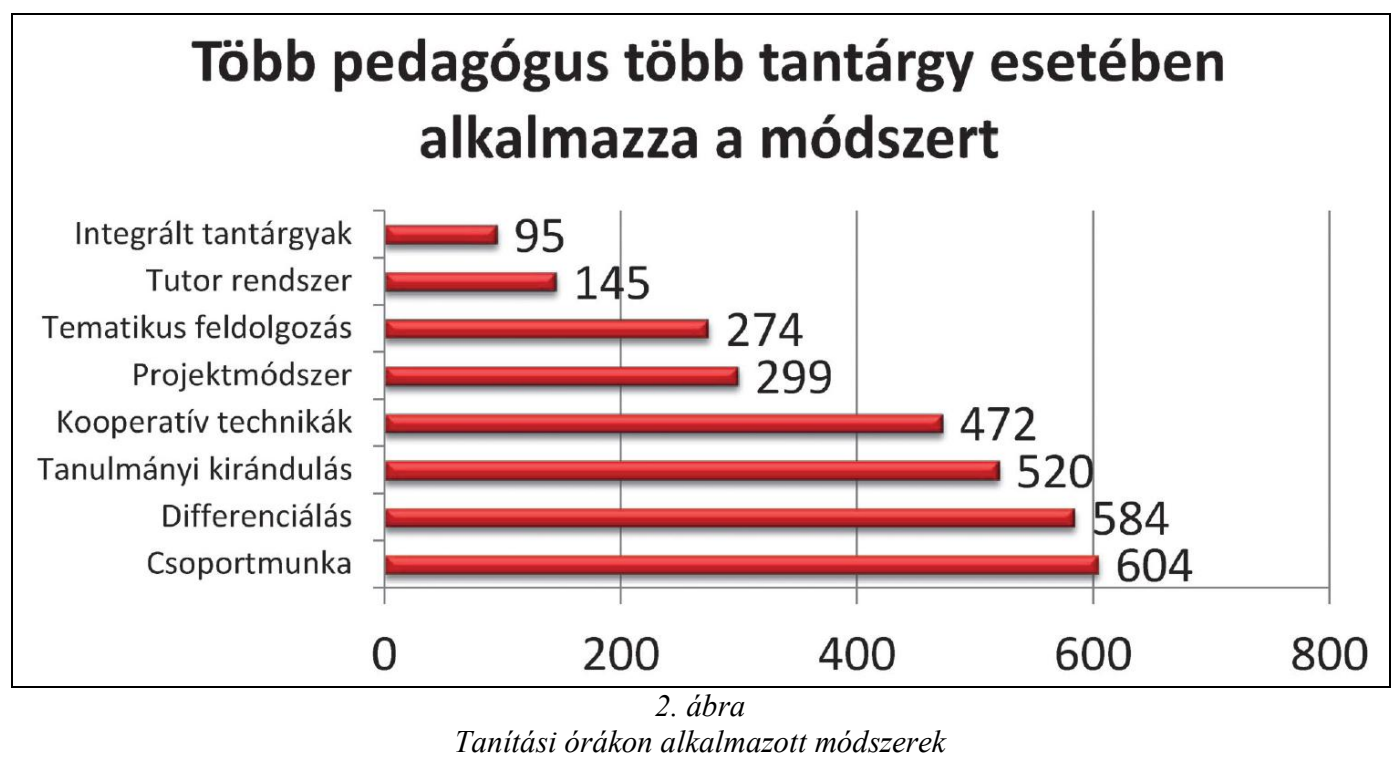

A szakkörökre és az egyéb órai tevékenységekre adott válaszokat összegezve kiderült, hogy ezen tevékenységek közül az „Ember és természet” illetve az „Erdei iskola” a legnépszerübb.

Terepgyakorlatot illetve zoo- vagy múzeumpedagógiát egyaránt 79 intézmény jelölt meg, ez a válaszadók 12\%-a. Az egyéb, természettudományokkal kapcsolatos szakköröket az alábbi táblázatban foglaltuk össze.

\begin{tabular}{|l|}
\multicolumn{1}{|c|}{$\begin{array}{c}\text { Egyéb, természettudományokkal } \\
\text { kapcsolatos szakkörök }\end{array}$} \\
\hline Természetjáró szakkör \\
\hline „Jövőkutatók” - energiaőrjárat \\
\hline Ökoiskolai programok \\
\hline Öko-, logikai játékok/táblajátékok \\
\hline Környezeti nevelés \\
\hline
\end{tabular}

A pedagógusok által igénybe vett eszközök adataiból látszik, hogy az interaktív táblára, és a határozókönyvekre tudunk építeni a fejlesztések során, hiszen ezek több iskolában is a gyakran használt eszközök között szerepelnek, bár a határozókönyvek és a biológiai modellek esetében is közel 100-100 iskola válaszolta, hogy ritkán használják ezeket az eszközöket. Figyelmet érdemlő jelenség a meglévő eszközök használatának mellőzése. A tanulói mikroszkóppal rendelkező iskolák mintegy 10\%-a soha nem használja ezeket az eszközöket. Jó lenne elérni, hogy a környezetvédelmi mérőkofferek és a tanulókísérleti eszközcsomagok se porosodjanak az iskolák polcain, különös tekintettel arra, hogy a saját tevékenységből nyert tapasztalatok így elötérbe kerülhetnének, mivel az adatokból az is látszik, hogy szemléltetésként leginkább a demonstrációs eszközöket használják a gyakorló pedagógusok. Több szempontból is érdemes lenne megvizsgálni, milyen tényezők befolyásolják, hogy a beszerzett eszközök, felszerelés, vegyszerek nem kerülnek elő a tanítási órákon. Amennyiben sikerül az 
okokat feltárni, célirányos támogatást lehetne adni az intézményeknek a felmerült problémák megoldásában. Ez azonban meghaladja jelenlegi kutatási kereteinket.
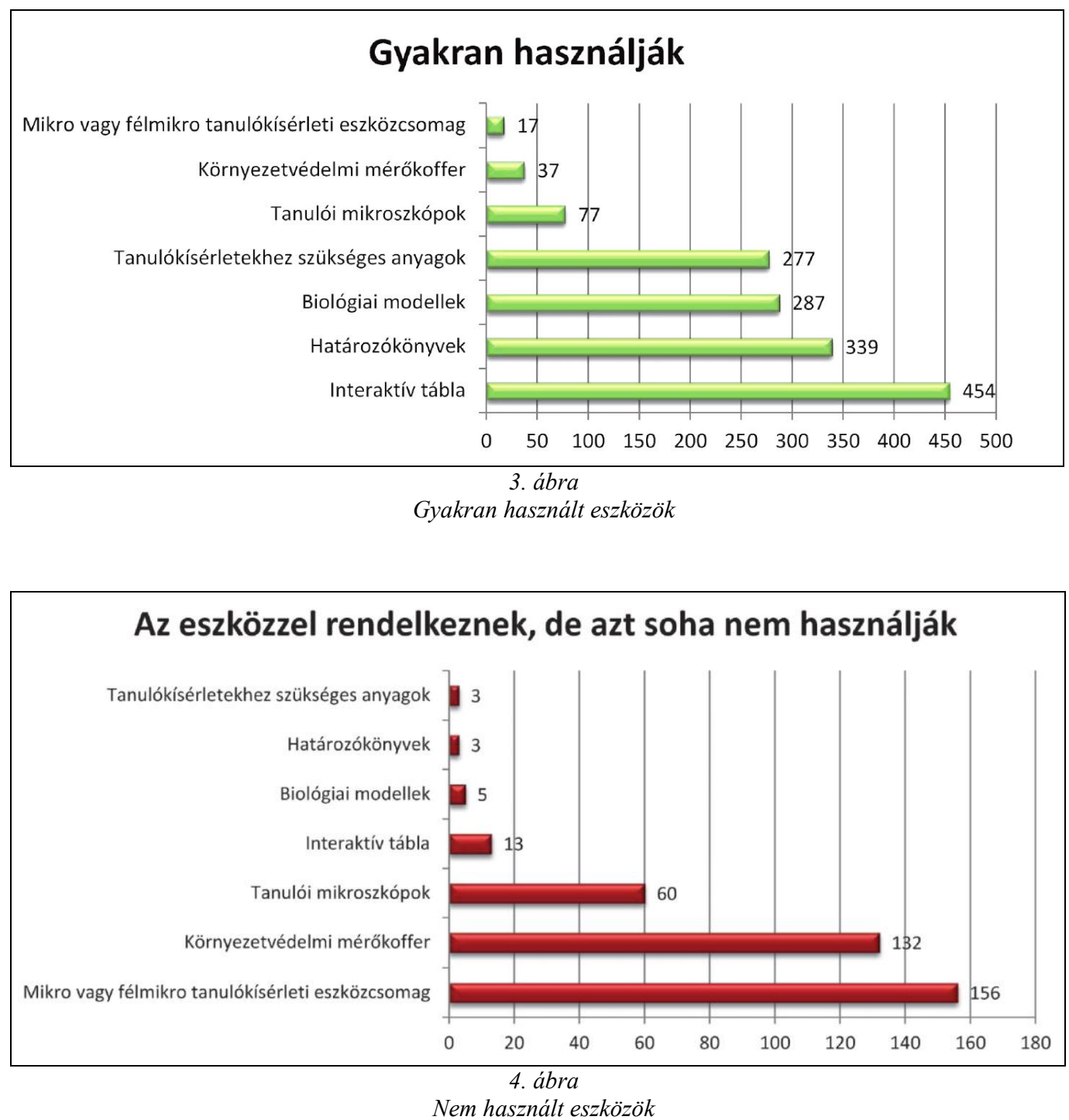

Az intézményben rendelkezésre álló infrastruktúra használatánál is megfigyelhetőek kiaknázatlan lehetőségek. Az ábrán az iskolakertnél láthatjuk megjelenni számottevő mértékben a „Van, de nem használjuk” kategóriát. Az előző elemzésekből kiderült, hogy kevés iskola rendelkezik iskolakerttel, és ezen kevés számú iskola közül is csak 86 iskola használja azt rendszeresen, vagy gyakran. A többi vizsgált infrastrukturális elemre nem jellemző ilyen „mellőzés”, általában használják öket az intézmények, föként a számítógéppel felszerelt termeket és a szaktantermeket. 


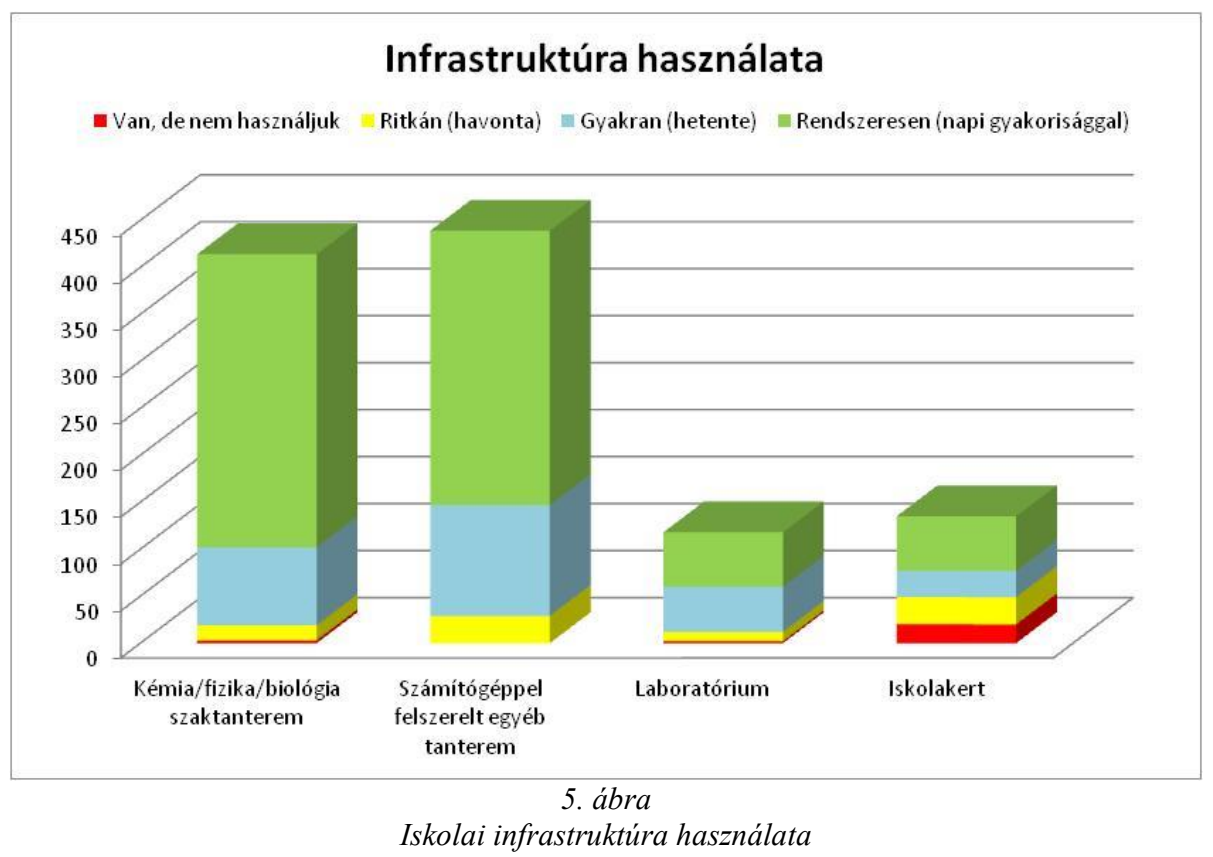

Az intézményben uralkodó természettudományokkal szembeni szemléletmódot tükröző válaszokból, két kérdést vettünk górcső alá. Az egyiknél azt vizsgáltuk, hány iskola sorolta az öt legfontosabb szempont közé a „Környezeti tudatosságra, fenntarthatóságra nevelés”-t, a másik kérdésünk arra vonatkozott, müködik-e az intézményben ökológiai munkacsoport.

A környezeti tudatosságra, fenntarthatóságra nevelés csupán az iskolák 21\%-nál szerepel a legfontosabb öt szempont között. A válaszadók közül csak ökoiskolákban jelenik meg ökológiai munkacsoport és külső partnerekkel való együttműködés. Az intézmények 40\%-ban müködik viszont az „Ember és természet" témakörhöz kapcsolható szakkör.

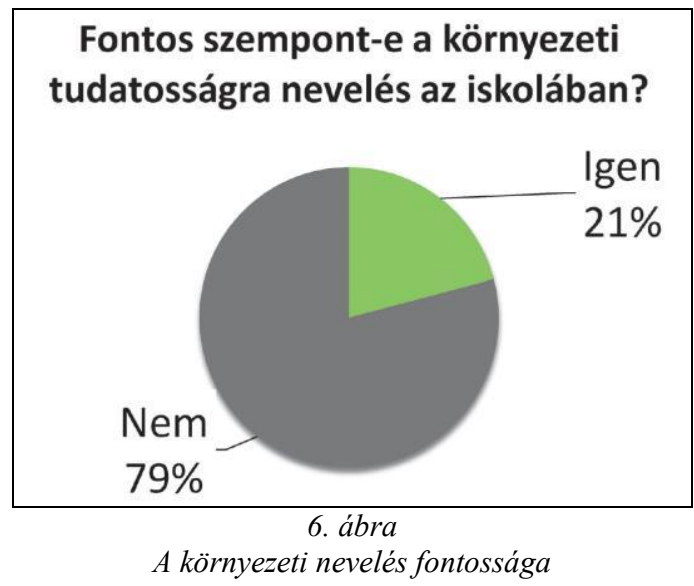

A válaszadó ökoiskolák közül a pedagógusok továbbképzése, és új módszerek alkalmazása sok intézményre jellemző, hiszen 93\%-uk nyilatkozott úgy, hogy a pedagógusok az elmúlt két évben alkalmaztak új módszereket a tanórákon, valamint kétharmaduk növelte az elmúlt két év során a továbbképzéseken résztvevő pedagógusok arányát. Az iskolák 70\%-ra jellemző, 
hogy vannak környezeti nevelés terén szakmai partnerségeik. Meglepő eredmény ugyanakkor, hogy kevesebb, mint az ökoiskolák fele érzi úgy, hogy a fenntarthatóságra nevelés terén sikeres lenne, az innovatív pedagógia alkalmazása, helyi innovációk területén pedig csupán kevesebb, mint egyharmaduk, pedig ezek is fontos elemei a fenntarthatóság pedagógiájának.

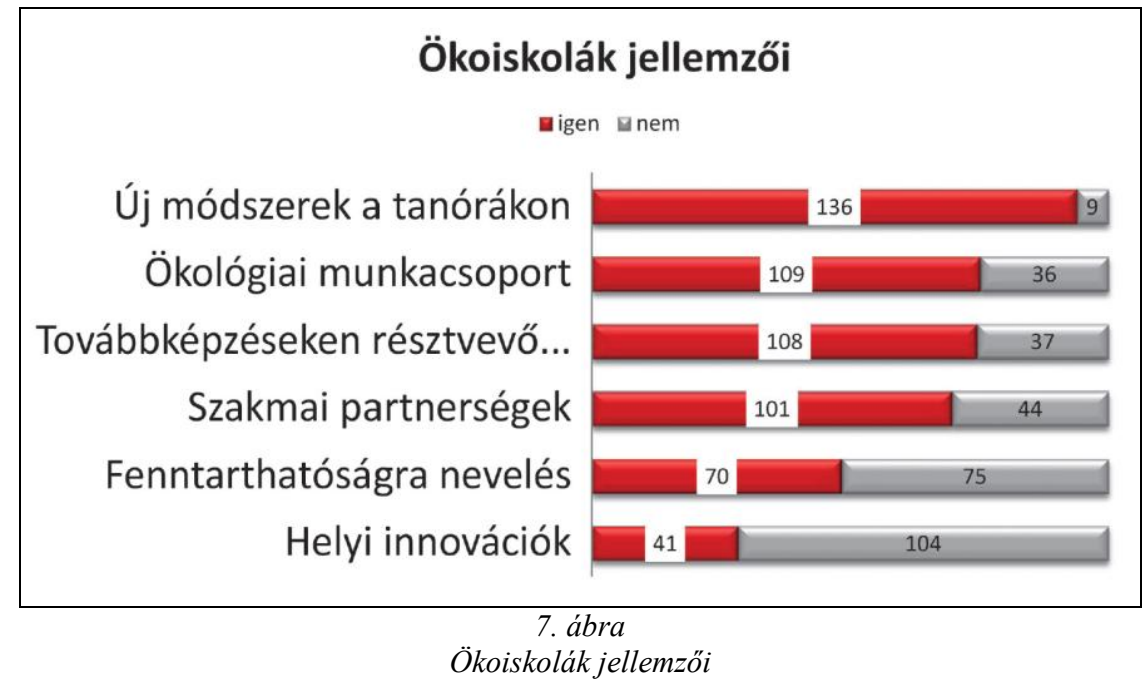

\section{Összegzés}

A TÁMOP-3.1.1 XXI. századi közoktatás (fejlesztés, koordináció) - II. szakasz kiemelt projekt 3. alprojektjének („A nevelés-oktatás fejlesztése, komplex pilot programok") online kérdőívének elemzéséből kiderült számunkra, hogy a pedagógiai módszerek közül a válaszadó iskolák tekintetében a csoportmunka, a differenciálás és a kooperatív technikák a legelterjedtebbek. Ezek jó alapot képezhetnek a felfedeztető tanulást támogató moduljainkhoz. Az integrált tantárgyoktatást ellenben nem sok helyen használják. Ez közvetlenül nem szükséges az általunk tervezett modulok alkalmazásához, ám a felfedeztető tanulási formák a természettudományokban mindenképpen megkövetelnek integrált szemléletmódot (tehát adott esetben egyszerre kell használnia a tanulónak a munka során a biológia, kémia vagy fizika órán elsajátított tudást). Az intézmények 40\%-ban müködik az „Ember és természet” témakörhöz kapcsolható szakkör, ami elengedhetetlen az egész napos iskolára fejlesztett moduljaink teszteléséhez, fejlesztéséhez. Szerencsés, hogy az eszközök közül a határozókönyvekre, illetve a tanulókísérleti anyagokra szinte mindenütt számíthatunk. Természettudományi szaktanterem, valamint számítógéppel ellátott egyéb tanterem a legtöbb iskolában van, használatában mind a pedagógusok, mind a tanulók gyakorlottak. Bár fejlesztésünknek nem konkrét célja, de elgondolkodtató lehet az iskolakertek oktatási célú használatának erősítése az egész napos iskola keretében. Az iskolák közel húsz százaléka tartja fontosnak a környezeti nevelést, amely szorosan kapcsolódik a természettudományokhoz, és szintén húsz százalékukban múködik ökológiai pedagógus munkacsoport. 
Az eredmények alapján, a meglévő jó gyakorlatokat, alapokat kihasználva, a fenntarthatóság pedagógiája és az aktív tanulási módszerek szempontjából kívánatos változásokat elösegítve szeretnénk projektünk keretében sikeres nevelési-oktatási programot alkotni, szoros együttmüködésben partneriskoláink gyakorló pedagógusaival.

\section{Irodalom}

Havas Péter (2009): A fenntarthatóság pedagógiai elemei. OFI, Budapest. http://www.ofi.hu/tudastar/fenntarthatosag

Lave, Jean (2009): The practice of Learning. In: Illeris, Knud (szerk.) Contemporary theories of learning. learning theorists... in their own words. Routledge, New York. 200-207.

Réti Mónika, Á. Majer Anna, Czuczor Judit és Lénárt András (2013): Fejlesztési koncepció az egész napos iskolák természettudományos nevelési programjának kidolgozásához, rövid szakmai anyag. OFI.

UNESCO-UNEP (1992): Promoting education, public awareness and training. In: Environment and Development, Agenda 21. United Nations Sustainable Development. 